\title{
A propos de l'article de Jouke S. Wigboldus : Salt and crop production in the precolonial central sudan - or lovejoy's poorly-developed-technology thesis
}

Pierre Gouletquer

\section{(2) OpenEdition}

\section{Journals}

Édition électronique

URL : https://journals.openedition.org/tc/711

DOI : $10.4000 /$ tc. 711

ISSN : 1952-420X

Éditeur

Éditions de l'EHESS

Édition imprimée

Date de publication : 1 novembre 1992

ISSN : 0248-6016

\section{Référence électronique}

Pierre Gouletquer, «A propos de l'article de Jouke S. Wigboldus : Salt and crop production in the precolonial central sudan - or lovejoy's poorly-developed-technology thesis», Techniques \& Culture [En ligne], 17-18 | 1992, mis en ligne le 10 janvier 2006, consulté le 29 septembre 2022. URL : http:// journals.openedition.org/tc/711 ; DOI : https://doi.org/10.4000/tc.711

Ce document a été généré automatiquement le 29 septembre 2022

Tous droits réservés 
A propos de l'article de Jouke S. Wigboldus : Salt and crop production in the precolonial central sudan - or lovejoy's poorlydeveloped-technology thesis

Pierre Gouletquer 